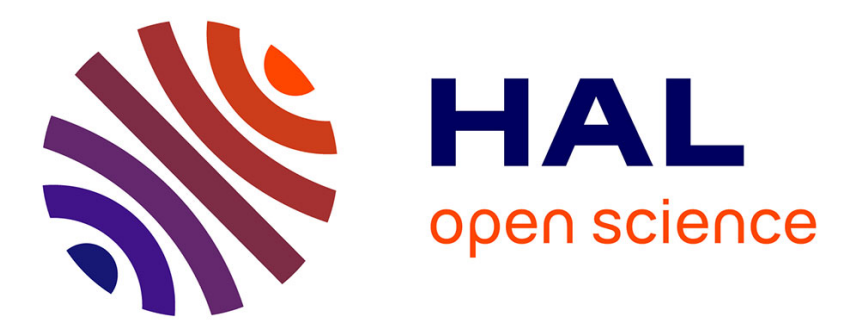

\title{
Does unemployment still have a meaning? Findings from a comparison of three conurbations
}

Didier Demazière

\section{To cite this version:}

Didier Demazière. Does unemployment still have a meaning? Findings from a comparison of three conurbations. Sociologie du Travail, 2014, 56 (Supplément 1), pp.21-42. 10.1016/j.soctra.2014.07.006 . hal-01524027

\section{HAL Id: hal-01524027 \\ https://hal-sciencespo.archives-ouvertes.fr/hal-01524027}

Submitted on 17 May 2017

HAL is a multi-disciplinary open access archive for the deposit and dissemination of scientific research documents, whether they are published or not. The documents may come from teaching and research institutions in France or abroad, or from public or private research centers.
L'archive ouverte pluridisciplinaire HAL, est destinée au dépôt et à la diffusion de documents scientifiques de niveau recherche, publiés ou non, émanant des établissements d'enseignement et de recherche français ou étrangers, des laboratoires publics ou privés.

\section{(이) $\$$}

Distributed under a Creative Commons Attribution - NonCommercial - NoDerivatives| 4.0 


\title{
Does unemployment still have a meaning? Findings from a comparison of three conurbations
}

\author{
Didier Demazière
}

Centre de sociologie des organisations, Sciences Po/CNRS, 19 rue Amélie, 75007 Paris, France

\begin{abstract}
There have been many international comparisons of unemployment (in the sense of the ILO), usually measured by applying codified indicators based on set norms. Our approach is entirely different. Compara-bility is not assumed in advance, simply by adjusting the measurement instrument, but itself becomes the object of investigation: is unemployment a meaningful and robust category that gives the jobless an identity in very different societies? In order to answer this question, the article outlines the different phases of a com-parative approach based on biographical interviews with unemployed people in three conurbations (Paris, São Paulo, Tokyo). A comprehensive comparison reveals both the robustness and the fragility of joblessness as a category, thus constituting a useful adjunct to standardised comparisons. In the tradition of figurational sociology, we see unemployment as a nexus, a point of intersection between normativities that vary with time and space and subjectivities that vary with social status and personal itineraries.
\end{abstract}

Keywords: Unemployment; International Comparison; Biographical Interviews; Experience

International comparison on unemployment has come to be taken for granted, in particular because it can be based on harmonized indicators. The codification of unemployment established by the International Labour Organization (ILO) is thus largely accepted and adopted by major national and international bodies that produce or use economic statistics. This measurement convention (known as "unemployment in the sense of the ILO") constitutes and maintains a definition widely accepted as valid, combining three criteria: joblessness, immediate availability for work, actual or active jobseeking. As each country translates the ILO recommendations into

\footnotetext{
放 First published in French: Le chômage a-t-il encore un sens ? Enseignements d'une comparaison dans trois métropoles. Sociologie du travail 55 (2), 191-213. Translation: John Crisp.

E-mail address: didier.demaziere@ sciencespo.fr
} 
a specific survey protocol, it is not only the methods that are harmonized, but also the results, the "outputs" (Desrosières, 2003). The problems inherent in any international comparison are nevertheless tackled, if not resolved, before surveys are conducted, through the production of standardized indicators that are assumed to be equivalent from one country to another,

There has been growing criticism in recent decades of the unemployment indicator forged by the ILO for international comparison, and more broadly of unemployment statistics in general. ${ }^{1}$ In fact, any definition of unemployment is very sensitive to the criteria applied, and the boundaries between unemployment, employment and inactivity are not easy to identify, ${ }^{2}$ especially with the development of factors such as occasional work, underemployment, discouragement or forced inactivity (Maruani, 2002; Demazière, 2006). The regulations and institutions of the labor markets specific to each country (benefits systems, unemployment policies, work/life balance arrangements, etc. $)^{3}$ directly influence both the volume of unemployment and the forms it takes, which are subject to wide international fluctuations. In the harmonized measurement of unemployment — the basis of international comparisons - and outside national performance rankings, this heterogeneity goes unnoticed, ${ }^{4}$ a fact that challenges the very concept of comparison.

Such a challenge is what we propose here, not by developing a critique of codified comparison but by reversing the perspective. Instead of treating comparability as a given through the use of harmonized measuring instruments, our aim is to make it the central focus of the research: can unemployment be considered as a pertinent and equivalent category in contrasting societies, in which salaried employment dominates and is becoming a norm of employment? ${ }^{5}$ Does this pertinence vary from one country to another? What is the range of variation? Is unemployment interpreted in the same way from one country to another, or is it perceived differently or indeed invested with irreconcilable meanings? While the term "unemployment" is widespread, is it really a robust category of identification, easily transposable from one place to another, or do its meanings become splintered and fragmented in the act of movement?

To ask these questions is to look at the conventional definitions of unemployment not as invariants that can be used to measure a phenomenon assumed to be objective and equivalent

\footnotetext{
${ }^{1}$ There have for several decades been recurring critiques of unemployment figures and of the ambiguities of the measurement methods used. For the French case in particular, such critiques include: Eloy and Vanderpotte, 1973; Castel et al., 1997; Goux, 2003. On the measurement of unemployment in the sense of the ILO, see Chardon and Goux, 2003.

${ }^{2}$ For example, how do you classify a student who works for a few hours a week, or who works part-time; an individual who wants to work but is not looking for a job, or is temporarily on a training course; a mother who is not immediately available for work, etc.? This issue of the overlaps between major social conditions (employment, unemployment, inactivity) was identified in the 1980s: Freyssinet, 1984; Cézard, 1986.

3 There is no shortage of illustrations, and a few examples are sufficient to show the institutional foundations of unemployment: in the Netherlands, increased flexibility in the rules of access to disability benefits has led to a reassessment of the number of people classified as unemployed by reason of disability (Jean, 2000); in the UK, the social protection and unemployment benefits system deprives many female part-time workers of all benefits and conceals a proportion of female unemployment (Hegewisch, 1998); in France, the oldest unemployed were until recently exempt from the requirement to look for work and received a guaranteed income, therefore de facto entering early retirement (Demazière, 2002).

4 The institutional dimension of unemployment is nevertheless placed at the center of certain comparative analyses, which take account of national differences in employment systems, social protection and family norms, in order to reflect variations in the gendered structure of unemployment (Benoit-Guilbot, 1987, 1989), in the impact of long-term unemployment (Benoit-Guilbot and Gallie, 1992) and in the lived experience of unemployment (Paugam and Gallie, 2004).

${ }^{5}$ Historical studies on the emergence of the category of unemployment as a way of perceiving, interpreting and then codifying certain forms of work deprivation clearly show that these processes become embedded in societies undergoing industrialization, where salaried employment becomes the norm (Salais et al., 1986; Topalov, 1994; Mansfield et al., 1994; Zimmermann, 2001).
} 
from one country to another, but as interpretative processes whose meanings can change in the course of experience and potentially vary between countries. In seeking to answer them, we had to devise a research method that makes the comparability of unemployment the central object of investigation. By focusing the comparison on individuals officially classified as unemployed and therefore conventionally comparable or equivalent, the aim is therefore to explore how they deal with joblessness and the meanings they attribute to it, to understand their own ways of narrating and interpreting their experiences, and finally to examine to what extent these "definitions of the situation" (Thomas, 1923) are comparable, shared, differentiated or incommensurable from one country to another. The primary goal is to contribute to the debate on how the phenomena compared are characterized, by making categorization a central focus of comparison, rather than its prior condition. Unemployment is not treated, therefore, as an already harmonized indicator, but approached as an object of interpretation, whose meanings and contours, hypothesized to be unstable and shifting, are at the heart of the issue of comparison. The interpretative comparative approach presented here questions the relevance of the category of unemployment: is it still meaningful and, if so, is its meaning singular or fragmented, is it embedded in national conditions or does it cut across them, what are its principles of variation, etc.? In turn, these questions prompt reflections on international comparison, in particular about the range of differences and resemblances between the spaces compared, between the social categorizations observable in those spaces: how should we approach the similarities and specificities of societies, and do these arise from national conditions or should they be explored by reference to other analytical dimensions?

Our study is based on a survey conducted in 2004 in three countries with contrasting sociohistorical trajectories and marked in different ways by unemployment: one European country where joblessness is persistent and high (France); an Asian country where strong economic growth has until recently contained it at a low level (Japan); an emerging country where sharp economic fluctuations have led to wide and cyclical variations (Brazil). In each of these countries, a metropolitan zone was chosen in order to restrict the enquiry to areas where unemployment is an appropriate and active category, which implies - as we learn from the history of unemployment - that the codification of work is fairly widespread. Concentrating the survey, therefore, on the Paris, Tokyo and São Paulo regions, we conducted in-depth biographical interviews with jobless people. $^{6}$

We begin by explaining our use of a "bottom-up" (Bayart, 2008) or "close-up" (Valensi, 2002) comparison, here based on biographical interviews, and elucidate the choices made — the areas chosen, the populations interviewed, the use of surveys - as a way of managing an approach that is not circumscribed by the constraints of a standardized protocol. In the three following sections, we explore the variety of the meanings of unemployment by measuring the similarities and differences observed, and successively offer: the identification of a shared or international universe of reference, the identification of normative models specific to the national spaces, the description of transnational social homologies. The experiences of unemployment are therefore embedded in multiple normativities: a common framework that preserves the substance of the notion of unemployment, while widening its spectrum of meanings; institutions specific to each territory that can be considered as national references; social differences that recur from one

\footnotetext{
6 The research was carried out by four researchers (Nadya Araujo Guimarães, Helena Hirata, Kurumi Sugita and Didier Demazière) with complementary expertise and backgrounds: experience of research and familiarity with the chosen areas, academic skills in the comparison between societies and/or in the sociological study of unemployment, fluency in two or three languages involved in the research. In addition, local researchers working on related topics or issues were involved in each region, in particular during the survey phase. See: Kase and Sugita, 2006; Demazière et al., 2013.
} 
space to another, reflecting a social division of unemployment. The interpretative approach elicits comparative intelligibility by combining proximities and distances within a particularly complex system, which can be interpreted in the terms of figurational sociology.

\section{An interpretative comparison}

The comparison here is based on the collection and analysis of biographical interviews with unemployed people. The aim is to understand their experiences of unemployment, more specifically their experiences as they recount them, i.e. interpreted, invested with meanings, linked within a narrative. The basic analytical operation consists in comparing the interviews in order to identify similarities and proximities, differences and contrasts in the viewpoints expressed. In this kind of interpretative approach, the volume of the research material is necessarily limited, which places serious constraints on comparison: how, in the choice of the areas investigated and in the demarcation of the samples interviewed, do we maintain a sufficiently wide range of variational hypotheses? These questions, which have been partially examined (Lallement and Spurk, 2003; Barbier and Letablier, 2005), demand a reflexive treatment of comparison, the broad lines of which are set out below.

\subsection{Territories where the marks of unemployment are contrasting}

Since the objective of the research is to explore the variety of the meanings of unemployment and, in so doing, to test the consistency of unemployment as a category, the territories chosen needed to be both strongly differentiated and comparable (unemployment must be a phenomenon clearly recognized by the population). The subnational scale offers a good terrain for interpretative analysis, because it provides a means to align biographical experiences more closely with the social frameworks — institutions, networks, partners - of these experiences. By contrast, the national context appears problematic in this respect (Wimmer and Glick Schiller, 2002), even though many public policies, legal norms or statutory codifications that contribute to the regulation of unemployment operate at this scale. We therefore opted for regional scale metropolitan areas, geographically quite large but also fairly consistent, being marked by sets of conventions that structure and underpin economic and social activities (Storper, 1997). While this scale is characterized by particular economic dynamics (Scott, 1998; Puga and Venables, 1999; Hall, 2001), these regions can also be considered as communities of meaning (practical norms, cognitive routines, sedimented experiences, shared beliefs) which contribute to the framing of individual experiences. The research was conducted in the Paris, São Paulo and Tokyo conurbations. These three areas show significant contrasts, since they are situated within very different geographical spaces, historical dynamics and political frameworks, and have been affected in specific ways by unemployment. ${ }^{7}$ The meanings invested in unemployment can nevertheless be compared, because the institutionalization of the employment system and social status (specific to each case) bestows a minimum degree of consistency on the unemployed state.

\footnotetext{
${ }^{7}$ In the period when the research was in preparation, France had a high unemployment rate (in the sense of the ILO) despite a recent fall (10.9\% in 1998 and $9 \%$ in 2002), Japan retained the lowest level despite a rising trend (4.5\% in 1998 and 5.4\% in 2002), and Brazil was undergoing the sharpest variation (7.6\% in 1998 and 9.5\% in 2002).
} 
Table 1

A few salient features of the condition of the unemployed in the three metropolitan contexts.

\begin{tabular}{|c|c|c|c|}
\hline & Paris & São Paulo & Tokyo \\
\hline $\begin{array}{l}\text { Properties of the reference } \\
\text { employment norm }\end{array}$ & $\begin{array}{l}\text { Permanent contract } \\
\text { Generalization }\end{array}$ & $\begin{array}{l}\text { Registrado na carteira de } \\
\text { trabalho } \\
\text { Symbolization }\end{array}$ & $\begin{array}{l}\text { Shûshinkoyô } \\
\text { (lifelong employment) } \\
\text { Segmentation }\end{array}$ \\
\hline $\begin{array}{l}\text { Varieties of employment } \\
\text { forms }\end{array}$ & $\begin{array}{l}\text { Very varied, so-called } \\
\text { atypical employment } \\
\text { contracts } \\
\text { Social protection }\end{array}$ & $\begin{array}{l}\text { Informal, independent, } \\
\text { outsourced labor } \\
\text { Lack of protection }\end{array}$ & $\begin{array}{l}\text { Temporary and } \\
\text { specialized or targeted } \\
\text { contracts } \\
\text { Less protection }\end{array}$ \\
\hline $\begin{array}{l}\text { Historical markers } \\
\text { of unemployment }\end{array}$ & $\begin{array}{l}\text { Long-standing and } \\
\text { persistent } \\
\text { Risk of exclusion or } \\
\text { casualization }\end{array}$ & $\begin{array}{l}\text { Resurgent and indistinct } \\
\text { Component of mobilities }\end{array}$ & $\begin{array}{l}\text { Recent and sudden } \\
\text { Collapse of the job } \\
\text { security system }\end{array}$ \\
\hline $\begin{array}{l}\text { Management by public } \\
\text { policies }\end{array}$ & $\begin{array}{l}\text { Strong and heterogeneous } \\
\text { Public institutions } \\
\text { Support }\end{array}$ & $\begin{array}{l}\text { Weak and uneven } \\
\text { Remote institutions } \\
\text { Scattered initiatives }\end{array}$ & $\begin{array}{l}\text { Limited and localized } \\
\text { Weakened institutions } \\
\text { Self-support }\end{array}$ \\
\hline $\begin{array}{l}\text { Unemployment (under } \\
\text { tension) }\end{array}$ & $\begin{array}{l}\text { An institutionalized but } \\
\text { increasingly fragile state }\end{array}$ & $\begin{array}{l}\text { A visible but unstable } \\
\text { state }\end{array}$ & $\begin{array}{l}\text { An emerging but } \\
\text { discriminated } \\
\text { state }\end{array}$ \\
\hline
\end{tabular}

The dynamics of the employment systems in these three areas exhibit a few similarities in the tension between the value attributed to a norm of employment and its destabilization. Of course, the contrat à durée indéterminée (permanent contract), the registrado na carteira de trabalho job and shûshinkoyô, are not equivalent, but they describe a well-identified and stable professional state. They are a distillation of historical processes that mark the territories and, beyond these, of systems of representation. They therefore constitute a norm, even if the normativity associated with them is different in each case (see Table 1): very wide diffusion and near-generalization (Paris), strong identification far exceeding its actual dissemination (São Paulo), foundation of an indivisible social compact of limited and segmented distribution (Tokyo). In parallel, the standard norm of employment is crumbling in ways that reflect processes specific to each place. This means that the different productive positions take different forms from one space to another and are situated at a different distance from the norm: strongly anchored in salaried employment and embedded in the standard system of social protection (Paris); including informal modes of employment or multiple forms of unsalaried work and reflecting conditions of very low social protection (São Paulo); leading to a specialization of employment contracts based on age or sex criteria that legitimize a lower level of social protection (Tokyo). Each employment system therefore revolves around tensions between a center (reference status) and a periphery, with varying degrees of intensity, distance, differentiation and distribution across the population.

These territories display very different unemployment trends and volumes. In addition, beyond the measurements, unemployment takes on heterogeneous meanings which appear as historical and social markers: it is associated with risks of exclusion and casualization once it becomes a permanent component of society and with growing fear of experiencing and becoming trapped in it (Paris); it is, to some degree, normalized, even diluted, when it features as one component among other phenomena of labor market mobility and fluidity (São Paulo); it is perceived as a threat to a highly valued system which constitutes the foundation of the professional and economic security of households (Tokyo). In view of this, it is no surprise to find that the institutionalization of unemployment, i.e. its translation into specialized institutions dedicated to the handling of the unem- 
ployed, is also variable: strong development of public institutions providing advice and support, and substantial protection through benefit mechanisms which are nevertheless heterogeneous and selective (Paris); poor institutional mechanisms on the labor market despite multiple scattered and remote initiatives, and welfare protection all the more fragile for the fact that labor relations remain formalized to only a limited degree (São Paulo); institutional action focused on the monitoring of the unemployed and encouragement to return to work, which favors autonomy and self-reliance in the unemployed, especially as benefits are limited and ad hoc (Tokyo). Nonetheless, while the condition of joblessness is demarcated by specific normative frames, nowhere does it seem unified: in each of the contexts, the boundaries and contours of unemployment seem blurred and give rise to a variety of meanings - as well as of categorizations of unemployment by the jobless themselves.

\subsection{Speaking of unemployment in three contexts}

Since the aim is to explore the fragmentation of unemployment as a category and to compare the multiplicity of meanings invested in the condition of joblessness, the survey population was targeted in such a way as to avoid any risk of tautology: a restrictive definition of the unemployed was used, corresponding to job seekers officially recognized, registered and monitored as such, within the legal or administrative definition. ${ }^{8}$ The survey population was targeted more precisely yet, in order to avert the scattering which, in the case of small samples, prevents the identification of internal variations. To this end, large variables that influence exposure to unemployment and more largely its distribution across social groupings (in particular age, sex, professional category) were taken into account, not by considering them in isolation (e.g. by ensuring minimum representation of men and women, age categories and professions in our samples) but by focusing on combinations corresponding to different positions in the labor systems. Four targeted populations were identified, defined by the following profiles: young people with minimal school qualifications seeking entry to the labor market ("youngsters"), mothers whose careers had been interrupted by a period of economic inactivity ("mothers"), unskilled and manual workers with family responsibilities who had experienced an employment glitch ("workers"), members of the middle classes whose career advancement had been destabilized by redundancy ("managers"). In all, 199 people were interviewed, broken down into equivalent proportions in the four target groups (Table 2).

A single protocol, designed to encourage people to talk about their experience ("relating to work", trabalho in Portuguese, shigoto in Japanese), their coping mechanisms, their activities, hopes and expectations, their interpretations of events and life episodes, was implemented in the three locations. Without a predefined set of questions, the interviewers only intervened to sustain the reflective narrative or to go back to an episode or event. The aim

\footnotetext{
${ }^{8}$ Given the different forms of institutionalization and codification of unemployment in each of the research locations, it was not possible to adopt the same protocol to identify and contact the respective survey populations: official recording of unemployment takes different forms. For this reason, in the places where registering as unemployed is a relevant practice, we chose an administrative definition of unemployment (jobseekers registered with the Agence nationale pour l'emploi in Paris, and at the Public Employment Security Office in Tokyo). Where the public employment service for the unemployed is more fragile or unevenly established, we preferred the ILO definition (respondents to the Pesquisa de Emprego e Desemprego [PED], classified as unemployed, in São Paulo). In each of the three cases, the aim was to reach - subject to the constraints encountered - what we might call the nucleus of unemployed people, i.e. the subset of the unemployed which, in each context, is considered to be the core of the category.
} 
Table 2

Breakdown into target groups of people interviewed in each metropolitan context.

\begin{tabular}{llllll}
\hline & Youngsters & Mothers & Workers & Managers & Total \\
\hline Paris & 17 & 19 & 20 & 17 & 73 \\
São Paulo & 12 & 14 & 19 & 12 & 57 \\
Tokyo & 19 & 15 & 15 & 20 & 69 \\
Total & 48 & 48 & 54 & 49 & 199 \\
\hline
\end{tabular}

of the subsequent analysis was to understand what unemployment (employment, work, inactivity, activity) represents for the interviewees, how they ascribe meaning to, consider, assess, describe, their situation. Here, the process of analyzing and reconstructing the meaning of the narratives (Demazière and Dubar, 2004) was complicated by the multiplicity of languages. We tackled this problem through a collective approach. Specifically, we opted for a method based on consensus (achieved by a series of arguments/counterarguments) in the different phases of the analysis. In so doing, we used French as the primary language, but rotated between the three languages of the interviews, plus English. While the activity of translation, defined as the shifts between the three working languages, was a constant of our analysis, ${ }^{9}$ it did not fundamentally change its nature insofar as it is not a component of a wider chain that leads to a transformation of the materials, expressed by the people interviewed in ordinary language, into analytical categories specific to the social sciences (Glaser and Strauss, 1967; Glaser, 1978).

\section{An international universe of reference}

Do the ways in which the interviewees talk about the experience of unemployment differ depending on the societies to which they belong? Do the differences in institutional and normative context make them incommensurable? The comparative analysis of the three sets of materials identified a set of similar and recurring meanings in the three contexts, enabling us progressively to trace a universe of meanings that may be called international because of this shared character. However, the outcome of this process cannot be a unified normative meaning, like that codified by international indicators relating to jobseeking and availability. In this sense, it is not a simple reflection of the international codification. It is made up of variations on that same norm; it is a universe of references or a map of shared meanings.

\subsection{Identifying shared meanings}

The identification of meanings that cut across the three cities drew on several methodological operations: selecting from each interview a series of extracts chosen for their expressive value; gradually establishing a record condensing the interviewee's point of view; comparing these

\footnotetext{
9 The establishment of a sort of trilingual dictionary which could be used to move between languages and thereby establish parallels between interviews organized around the same terms, is a dead-end, even though translation of the key terms in a field can be, as it were, contextually helpful (Jobert et al., 1995). Instead, we employed revisable and revised translations, adopting for our own purposes analyses on the indeterminacies of translation (Quine, 1960). Interpretative comparison is a continuous and always provisional exercise in translation. It is also a collective activity, in which negotiations within the research team were conducted in order to reach a reasonable result.
} 
Table 3

Implications of three typical meanings of unemployment.

\begin{tabular}{llll}
\hline & Competition & Discouragement & Resourcefulness \\
\hline Implications & Jobseeking & Impotence & Multiple activities \\
for the present situation & Trials to overcome & Unavoidable failures & Opportunities to grasp \\
Implications & Foresight, progress, & Giving up, depression, & Adaptation, contrivance, \\
for actions undertaken & planning & withdrawal & survival \\
Implications for & Anticipation of a & Fear of the future, & Uncertainty about the \\
future projections & foreseeable or planned & combined with taking & future and investment in \\
& future & refuge in the past & the present \\
\hline
\end{tabular}

records and looking for proximities and similarities of meaning; assessing the weight of an interpretation identified as common to all three sets of material in order to assess its significance, etc. These operations were used to tease out and clarify what might be called typical meanings, consolidated through recurrence.

The notion of discouragement, for example, was fairly quickly identified in this set of records, not in the sense of a fall in the intensity of jobseeking behaviors as measured by statistical surveys, but to describe an interpretative angle, a definition of the situation, a system of beliefs. It is a way of speaking about unemployment, characterized by a few salient characteristics: inability or great difficulty to imagine a future that seems a dead-end; sense of powerlessness in relation to life events that have brought a deterioration in the conditions of existence and the loss of or expulsion from employment; negative perception of the experience of a situation which seems inescapable. As a result, the search for a job is experienced as a succession of failures and seen as a pointless, hopeless activity.

Demoralization in the face of unemployment is a feeling that is found in a large number of accounts in the three groups, accounting for slightly over $20 \%$ of each set (some fifteen interviews for Paris, a dozen for São Paulo, fifteen or so for Tokyo). This categorization reproduces the findings from the oldest sociological surveys - starting in the 1930s and extensively developed since - which emphasize the extent to which unemployment signifies loss of status, a feeling of humiliation, social decline, withdrawal from all participation in community life (Lazarsfeld et al., 1981; Ledrut, 1966). In this sense, it reflects an experience that may have been considered as typical of the unemployed person's condition, as the objective truth of that condition (Schnapper, 1981). As a result, it is easy to imagine that discouragement might be a constant, clearly present in each of the three sets of interviews. This indication is a long way from the official, statistical or institutional definition, in which jobseeking is the core of unemployment. It represents an inverted form, a photographic negative, and for that very reason a translation: it symbolizes the internalization of a normative program and the impossibility of conforming to it. And it would seem to be a general, international and perhaps universal reference for the explicit attribution of meaning to the experience of unemployment. However, it is only one meaning amongst others, a component of a more diverse universe of reference, which includes other meanings identified, such as competition or resourcefulness (Table 3), which encompass different ways of interpreting joblessness, of finding answers to unemployment, of making projections into the future. 


\subsection{Calibrating proximities and distances}

Beyond these few examples, the meanings of unemployment identified in the biographical narratives form a dense corpus, not easy to break down into a typology, resistant to classification based around a few attractors. The typological approach seemed ill suited to our comparative objectives, which required us to retain as much heterogeneity as possible in all the interview content, in order to ensure that any crosscutting categories identified would not arise from a drastic reduction in the complexity of these meanings, or appear to be an artefact produced by their aggregation around a few characteristic references. The typological approach, which clusters units of empirical meaning around clearly distinct attractors each impermeable to the others, arises from a differentiation that places little value on continuities and variations in meaning. In addition, the meanings elicited by our analysis do not form sufficiently uniform and distinct ensembles for any typology to emerge. No doubt, the comparative approach has something to do with this, because it accentuates the heterogeneity of the language components (through multilingualism) and increases the difficulties of understanding the narratives (which reflect very different societies).

Rather than trying to explain patterns of meaning in isolation by fitting them into types, therefore, we sought to maintain the heterogeneity of the indigenous narratives, to record their nuances, and to identify the organizing principles of their variety. So here, the aim is less to define fixed points of meaning than to retrace the connections between the meanings attributed to unemployment, and to delineate a zone of distribution which integrates the whole into a structured map. In order to do this, we explored the variations in the typical meanings previously identified, with the aim of describing them in extenso and thereby identifying declines, combinations, points of contact, in other words boundary categories. This led us to outline clusters of meanings, which we sought to connect and situate in relation to each other, in a dual process of organization of the material and gradual theoretical formulation. We also used these iterative operations as a way of gradually integrating all the interviews. In this fashion, through trials and corrections, we drew up a map of meanings which situates each interview not within an isolated type, but in a part of the map, characterized by variation, continuity, polysemy and the flow of definitions of the situation. ${ }^{10}$ The final map (Fig. 1) is structured in two dimensions, each of which provides a gradation of relations to unemployment: based firstly on how this time of deprivation, absence, inactivity was filled, and secondly on the kind of escape and outcome anticipated.

The first dimension (the vertical axis of the map) indicates that certain interviews are structured as narratives of resourcefulness, in the sense of contriving solutions. Here, unemployment is incorporated, even dissolved, into an ensemble of strategies and activities that spill over and

\footnotetext{
10 The coordinates of each interview are partly approximate for methodological and theoretical reasons developed elsewhere (Demazière et al., 2013). The map of meanings is not the outcome of a mathematical algorithm, such as a factorial diagram, but of a gradual analytical development arising from the inclusion of a growing number of interviews. Its aim is to place the emphasis on flow, conversion, dynamics, heterogeneity or ambivalence in the ways in which the condition of joblessness is interpreted. In this sense, the map constitutes a continuous space and each individual narrative obtained though interview could be shown as a stain occupying a certain area — varying from case to case — within this space. For reasons of clarity, we made another representational choice by reducing each interview to a point, whose position seems to us to reflect the dominant and most strongly expressed meaning. To do this, we looked not only at the lexical categories used, but also at declarative evaluations that expounded differential values, and also at the discursive forms in which utterances were made (conditionalities, chances of realization, conditions of possibility, etc.). Situating each interview at a fixed point on the map is a reduction necessary for graphic depiction, which also makes it possible to treat the (slightly) floating nature of the positioning of each interview as a theoretical fact, not a methodological approximation.
} 


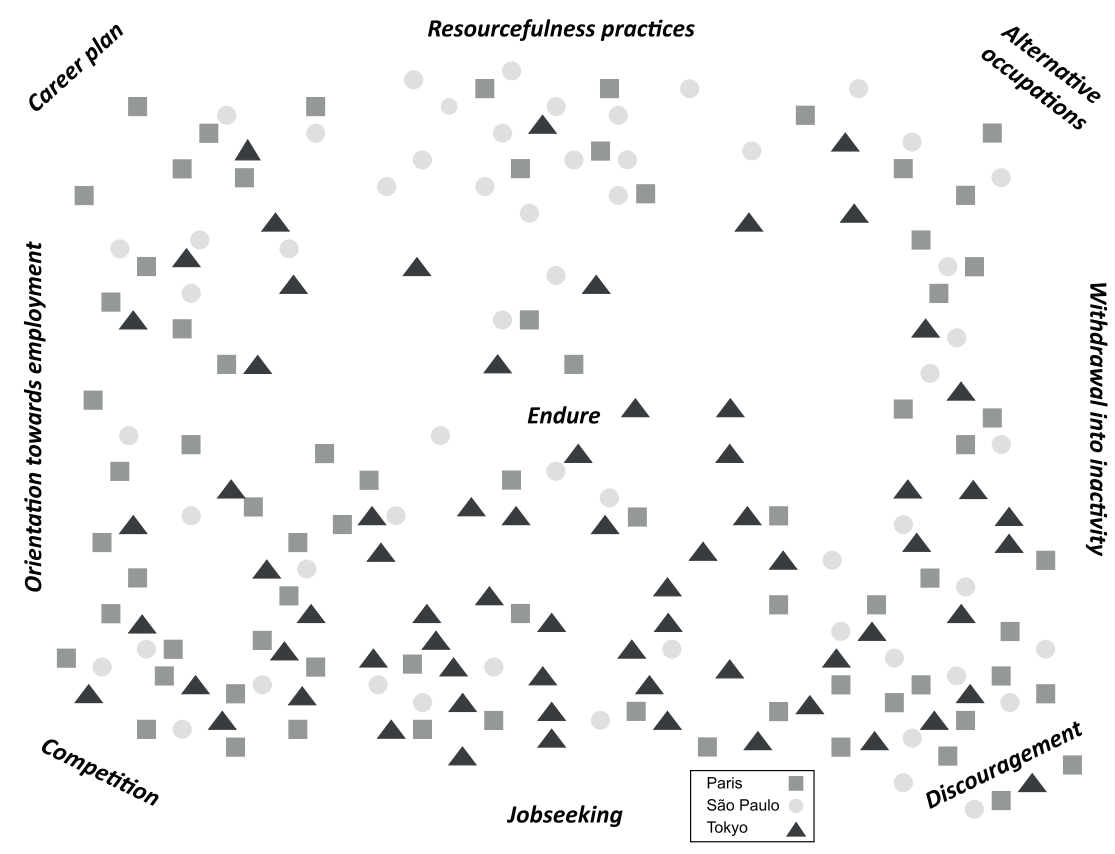

Fig. 1. Positional map of all the interviews.

turn it into a secondary component of the situation. Conversely, other interviews develop narratives structured around the search for a job and focused on that search. Unemployment is then narrated as the absence and deprivation of work, and becomes an all-pervasive component of the situation. The tension between resourcefulness narratives and jobseeking narratives is played out in the spectrum of future projections (which structure the map's horizontal axis). When a job is the shaping objective, the tension is between reinterpreting activities as a career plan, on the one hand, and a rational and efficient commitment to the competition for jobs, on the other. When withdrawal into inactivity is the attractor, this tension lies between the translation of activities into less vital occupations and falling back on alternatives that indicate the relinquishment of work, on the one hand, and on the other hand routinization and loss of meaning in the search for work under the pressure of accumulated failures, and the slide into discouragement. In the intermediate zone, the tension is characterized by a mix or oscillation between alternative occupations and commitment to the search for employment, which marks a persistent uncertainty about future prospects between employment and inactivity - an attitude of wait-and-see or relative indeterminacy.

For the second dimension, certain interviews seem to be framed as narratives of access to employment, with behaviors focused on obtaining a job and unemployment seemingly perceived as a form of presence on the labor market, directed towards the recovery of professional status. Other interviews, on the other hand, resemble narratives of withdrawal into inactivity, slanted towards the search for a tolerable alternative state that will provide a final or temporary escape from an increasingly painful and difficult situation. In this case, unemployment is defined as a waiting position, an antechamber to non-working status. The intensity of the tension between employment and inactivity narratives also arises from the accumulation of their variations in day-to-day behaviors. On the resourcefulness side, the tension lies between strategies in a plan to 
find work - whose implementation often proves uncertain - and the development of alternative occupations intended to obtain social utility connected with the anticipation of protective status. On the jobseeking side, it lies, on the one hand, between strategies of engagement in the competition for jobs and projected career plans, and on the other hand between entrenchment in discouragement and impotence, leading to marginalization devoid of all protection. The median area of these tensions, i.e. activities situated between employment plans and alternative occupations, on the one hand, and jobseeking situated between competition and discouragement, on the other, is associated with a particularly high degree of uncertainty: these are more ambivalent positions that may presage either employment or withdrawal.

All 199 interviews were positioned on the map, which indicates that the interpretations of unemployment can, in each of the territories compared, be understood by means of the same analytical categories. In other words, as different as these territories are, they share a single universe of reference. This universe bears the imprint of a general and international norm of unemployment, since a majority of the narratives of experience are located in the lower part of the map, where the meaning is organized around the search for employment, which is the core of official categorizations. However, this norm is not sufficiently powerful to guide all definitions of the situation, since the scattering of the interviews in the other parts of the map is a sign of great variety in the interpretations of unemployment.

\section{National normative models}

Although they fit on a single map, do the meanings of unemployment vary between the conurbations studied? By comparing the distribution of each of the three samples within a single space of meanings, we can identify strong specificities, and an in-depth analysis of the interviews for each conurbation leads us to interpret the differences in terms of national (or regional) normative models.

\subsection{Managed inclusion and multi-normativity (Paris)}

The interviews conducted in the Paris region divide into two primary clusters: the biggest is close to the center of orientation towards employment, the other focused around withdrawal into inactivity (Fig. 2). This polarization should not be seen as inconsistent: the aim is to understand how the characteristics of the biographical narratives are linked to normativities specific to the context, and in this case, to a relatively institutionalized and consistent form of unemployment management.

On the orientation towards work side, the definitions of the situation are highly fragmented: emphasis on jobseeking structured around a set of competitive criteria, construction of a career plan whose implementation will provide access to employment, explanation of varied options entailing phases of training, support, advice, etc. The common feature is that the connections between unemployment and employment are drawn tight by the support of public policies aimed at the unemployed, and by the solid institutionalization of unemployment. It is therefore the experience of unemployment itself which is managed and waymarked. Firstly, because it becomes a shared experience, which is the subject of public discourses and initiatives and, for that very reason, is not ascribed to individual responsibility alone. Second, because the specialist institutions and procedures are vehicles of normative requirements imposed on the unemployed. And finally, because the codification of jobseeking protocols, and their dissemination to the unemployed through multiple training courses, mold individual behaviors. 
Additionally, this institutionalization also functions selectively, distancing certain unemployed people from the labor market with various degrees of force, and disconnecting unemployment from employment to steer their experiences towards inactivity. Here again, this process is institutionalized, in so far as it is underpinned by a range of alternative statuses. For example, older people can think about early retirement, or even access age-related measures that sustain this definition of the situation. The most vulnerable can try to join category-specific protective systems set aside for populations defined by disabilities or acute social problems. Yet others can envisage adopting specific roles that attract a minimum degree of social recognition (such as that of housewife and mother or indeed, activist).

There are therefore multiple socially embedded, if not legitimate, ways of living and speaking the experience of unemployment, of interpreting the condition, of anticipating its end. In this sense, even though the legal model of the jobseeker constitutes a powerful reference, clearly apparent in the respective balances between competition for jobs or discouragement, it is not an exclusive reference. The experience of unemployment - except for discouragement, which lies outside the frameworks of status - is akin to managed inclusion within a highly differentiated range of states. It appears to be part of a multiplicity of norms, dominated by support into work and by jobseeking, whereas withdrawal into inactivity and the quest for alternative statuses are secondary. As to the practices of resourcefulness, they remain marginal and outside this multi-normativity, although in some cases they evolve towards withdrawal organized around alternative occupations or towards the preparation of a career plan with a view to future employment. Although certain unemployed people develop such resourcefulness practices, these are hardly mentioned as giving meaning to unemployment.

\subsection{Organized resourcefulness and alter-normativity (São Paulo)}

The interviews conducted in the São Paulo conurbation show a scattered distribution, but the attractive force of resourcefulness is apparent (Fig. 3). The experience of unemployment thus seems conspicuously marked by the pursuit of varied activities of fluctuating or uncertain status. By contrast, jobseeking is markedly more marginal as a repository of relevant meanings. While these specificities arise from biographical narratives, they are also reflections of the forms in which statuses and activities are codified and classified, and of the means used to manage joblessness.

The importance of resourcefulness reflects the limited nature of the legal provisions, whether applicable to employment, unemployment or inactivity. First, the forms of work are less confined to employment than in the other two regional contexts: paid work covers a wide spectrum running from formal employment status to more informal and undefined activities (undeclared jobs in industry and retail, street selling, day laboring, unofficial businesses, helping out, etc.). As a result, many unemployed people, in particular those who have not worked long-term in an officially registered job (carteira de trabalho), consider employment to be a restrictive entity compared with the variety of options for earning money in exchange for labor. For a good many, paid activities, although at very variable levels, represent a more accessible or more relevant goal than salaried employment as a response to unemployment.

Jobseeking, understood in the conventional sense of responding to job offers, is only significant for unemployed people who have experienced long periods of formal employment. More generally, it can be equated with the search for an activity that will provide a small income and as the application of resourcefulness. The very low level of withdrawal into inactivity is also explained by how little codified this condition is: even retirement, defined as a status in which it possible to live permanently without work, is not a pertinent objective since the pension associated with it is 

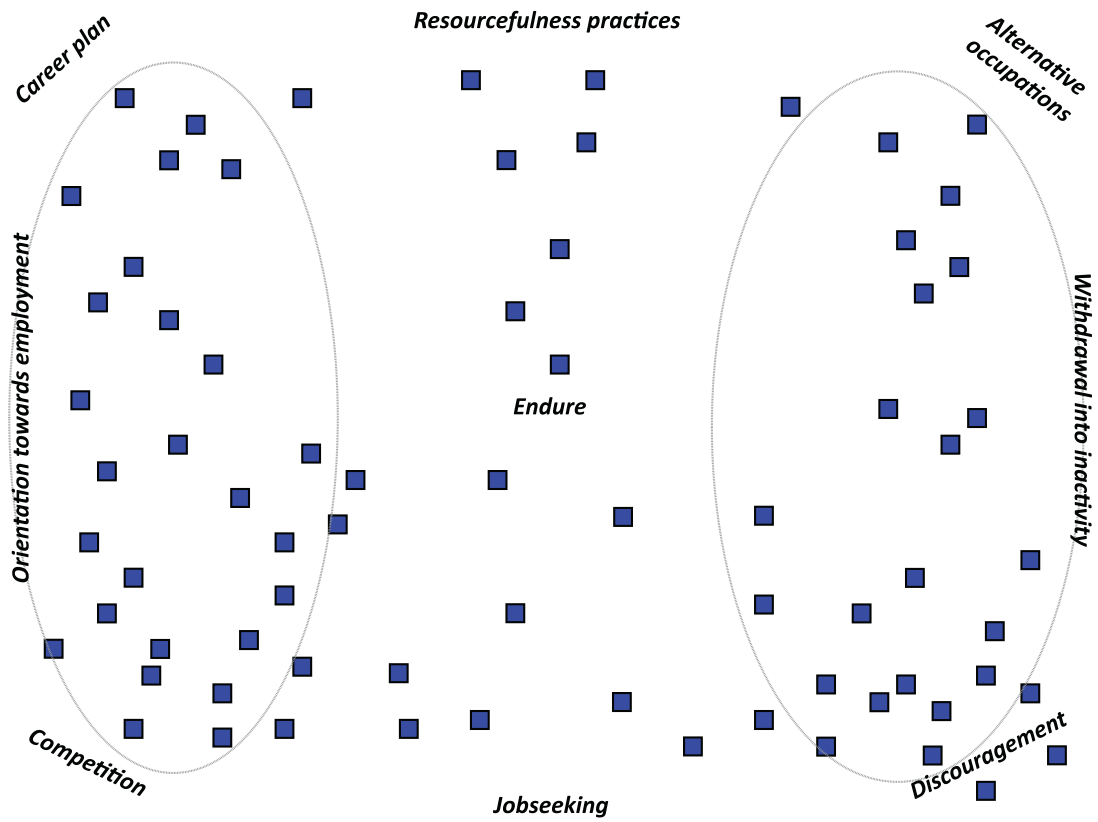

Fig. 2. Map of interviews in Paris.

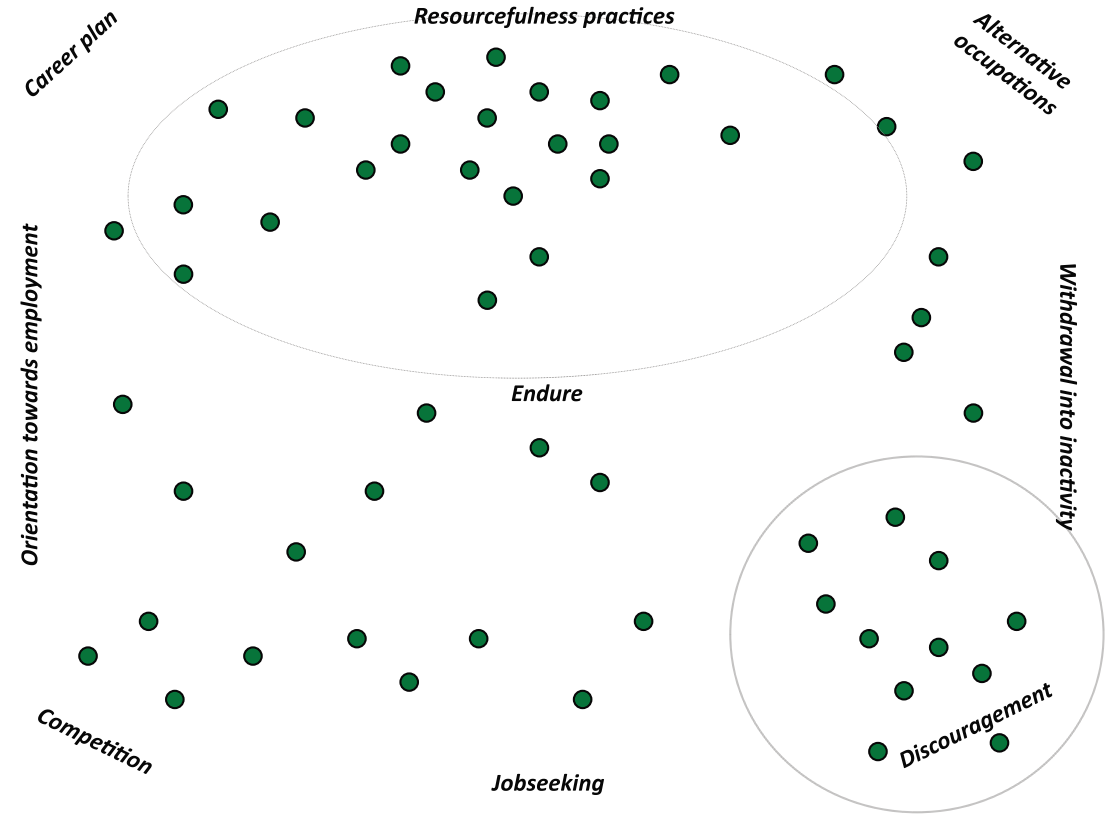

Fig. 3. Map of interviews in São Paulo. 


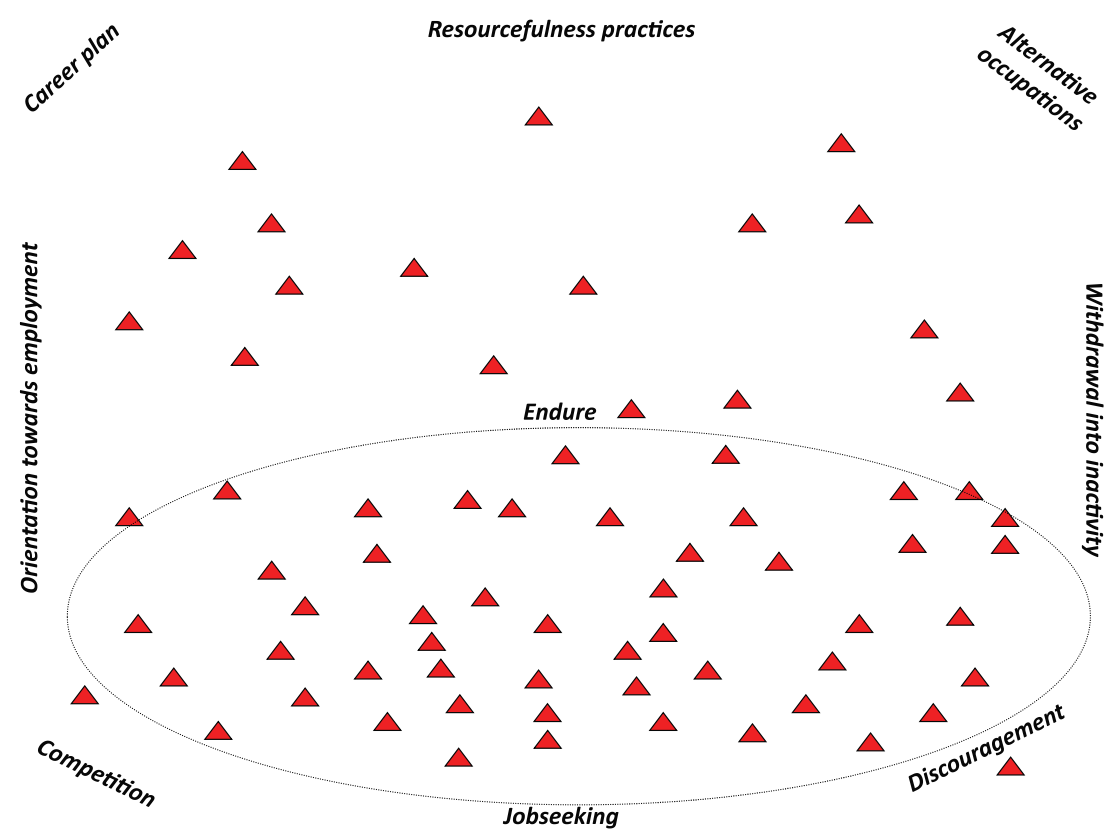

Fig. 4. Map of interviews in Tokyo.

often no more than a small monetary supplement to the earnings obtained through resourcefulness practices. As a result, this pension is not sufficient to give meaning to the experience of being able to escape unemployment. The systems of redistribution and social protection are hardly structured to provide the conditions of protected inactivity in the case of temporary or permanent inability to work.

Protection against the consequences of unemployment comes through local networks, made up of bonds of allegiance, obligation, reciprocity, and also servitude, which draw on resources that favor participation in activities whose status is uncertain but whose economic and monetary dimension is real. While the experience of unemployment, in the São Paulo case, is described in multiple ways, one of them dominates and constitutes a de facto norm: the practice of resourcefulness activities structured by relational bonds. Compared with the legal norm of jobseeking status, it is less a deviation or a transgression than a different - inverted - normativity, what we call alter-normativity. This practical norm is based on a specific way - embedded in social relations — of dealing with the absence of work and income. Unlike the institutionalized management found in the Paris region, what we see here is socialized management distributed within multiple groups and networks. The Japanese situation is different again.

\subsection{Personal responsibility and hyper-normativity (Tokyo)}

The distribution of the interviews conducted in the Tokyo region is heavily unbalanced, since almost all of them fall in the lower half of the map: they are a long way from the resourcefulness area of the map and scattered across the whole continuum of jobseeking forms, from competition to discouragement (Fig. 4). Looking for work seems highly significant and constitutes the reference 
horizon for a large majority of the Japanese unemployed, which reflects the ways in which the condition of joblessness is codified, recognized, framed.

The experience of unemployment is defined by reference to jobseeking, in certain cases active or aggressive, in others hesitant and uncertain, and in yet others gnawed by doubt and discouragement. Here, the norms of projection into a job and of looking for work form a restrictive framework for the unemployed, which singularly limits their ability to interpret and reinterpret their situation. The rigidity of this normative model is further exacerbated by the poor collective management of unemployment: public support is underdeveloped and devalued, relational networks are little used and associated with reticence and embarrassment because of the dependencies they generate. As a result, a large proportion of the unemployed are left to handle unemployment on their own. True, they are not totally cut off from public mechanisms, from support networks, from wider solidarities and family support, but these forms of assistance do not erase the referential meaning of unemployment, which is that it is an ordeal to be overcome by personal motivation, the only avenue to competing successfully on the labor market.

In addition, alternative interpretations appear marginal, even illegitimate. For example, the low level of resourcefulness undoubtedly arises from the power of statutory framings. It is as if situations were so formally and rigidly codified as to make it difficult, even impossible, for individuals facing unemployment to contrive intermediate options. This does not mean that no unofficial economy exists, but at the least that it does not constitute a sufficiently legitimate reference to provide the ingredients for a subjective interpretation of unemployment which could be expressed in a research interview (the only cases in which interviewees in the Japanese group spoke of their involvement in activities that diverted them from the search for a job are, in fact, limited to obligations arising from their membership of local communities). As for withdrawals into inactivity, this type of acceptance of unemployment is invariably expressed only in relation to alternative statuses (retirement) and in cases where identification with such a state is socially legitimate (notably because of an established division of work between the sexes).

There is thus a dominant way of interpreting the experience of unemployment, which is to situate it within the framework of the search for a job. Of course, the definitions of the situation expressed in the interviews vary in the degree to which they adhere to this model. However, it clearly constitutes a highly influential standard of reference, a hyper-normativity. Moreover, it is a vehicle and medium for a specific relation to the condition of unemployment, marked by loss of status, but also and above all by a process of internalization whereby it is the individuals concerned who are responsible for their fate and future. This norm of personal responsibility tends to isolate the unemployed from public institutions and relational networks. In this respect, and by contrast with the other two contexts, the management of unemployment in Tokyo seems internalized, rather than institutionalized (Paris) or socialized (São Paulo).

We were able to identify substantial differences in the distributions of the interpretations of unemployment in the three regions analyzed: managed integration dominates in Paris, organized resourcefulness rules in São Paulo, personal responsibility prevails in Tokyo. The differences between these three contexts are considerable, even though they form part of the same system of intelligibility. There is a specific normative framework corresponding to each space, which demarcates the condition of joblessness and circumscribes the subjectively relevant and socially expressible definitions of the situation. The power of these normativities varies according to the context: in Tokyo, the influence of the norms seems more significant and leaves little room for heterogeneity in the definitions of the situation (hyper-normativity); in Paris, the norms are transmitted by concrete institutions which support and manage the unemployed, and the latter can situate themselves in relation to a broad and diversified status range (multi-normativity); in 
São Paulo, the norms of practice are less the product of formal and codified institutions than of collective and network-based ways of handling unemployment, which underpin an interpretation of unemployment founded on the relativization of the search for work (alter-normativity). These three categorizations constitute a reference, but do not exhaust the interpretations of unemployment. They can nevertheless be considered as (national) models insofar as they do not represent gradients of intensity, or of force, in the international norm of jobseeking, but are contextualizations of that norm, which reflect the associated biographical experiences and subjective processes as well as being the expression of institutions and normative frameworks. The notion of a model used here does not presuppose a homogenization or uniformity in the definitions of the situation, and variations internal to each context, to each set of interviews, also need to be recognized (Figs. 2-4).

\section{Transnational social homologies}

As references, the models identified are subjective and normative, individual and collective. However, they do not exhaust the full range of experiences of unemployment, since a significant proportion of the interpretations of unemployment, depending on the context, falls outside their orbits. We therefore need to take the analysis further in order to try to understand the general economy of these variations, because international comparison should not blind us to other differences: we are thinking of infranational scales, increasingly often recognized, but also transnational processes, i.e. processes that cross - without necessarily expunging them - borders and operate in a multiplicity of countries. We can follow this path by including in the analysis the social characteristics of the unemployed, which were differentiated and tracked by the strategy of sampling into target groups. These groups were formed on the basis of combinations of social properties that reflect different positions on the labor market, different places in systems of kinship, disparate career histories. ${ }^{11}$ They can add another level of comparison, relating to inequalities in the experience, interpretation and categorization of unemployment: the mothers group was formed as a distillation of gender-based differences; the youngsters group helps us to understand differences of position based on age; workers and managers reflect different hierarchical levels in the division of labor. Through comparative analysis, therefore, we can combine the international and national levels with the level of social relations (sex, age, class), by identifying transnational social homologies.

An overview of the social variations in the meanings of unemployment can be achieved by adding the individual memberships of the four target groups to the previous map (Figs. 5-8). Whichever of the target groups we consider (managers, workers, mothers, youngsters), the distribution on the map is widely scattered, and never confined to one or other of the subspaces.

\footnotetext{
11 The four target groups were constituted around clusters of characteristics intended to offer an approach to these indissolubly subjective, institutional and relational processes. They each relate to social groupings largely accepted by the individuals attached to them. For example, the figure associated with the workers group is the adult whose life is fully committed to work, the masculine model of the head of the household charged with family responsibilities, and the regular worker whose life is destabilized by unemployment. The figure associated with the mothers group is women who combine a family and professional role, female workers whose working life is interrupted and complicated because of these choices, and also re-entry into the labor market as a cause of unemployment. The figure associated with the youngsters group is the young man or woman entering adulthood and the specific uncertainties associated with this stage of life, with underqualified jobseekers facing difficulties in professional integration. And finally, the figure associated with the managers group is the adult embedded in working life, the integrated middle classes with relatively comfortable living conditions and the individual who has experienced a degree of career success, interrupted by an unforeseen event.
} 
This means that the variety of interpretations of unemployment is a constant, which cuts across social categories. Nonetheless, the distribution varies markedly from one target group to another: managers are more strongly orientated towards employment than workers, who for their part are more prone to discouragement; there are more mothers of the inactivity tendency by contrast with youngsters, etc. The biographical experiences of the unemployed thus also contribute to the categorization of the experience of unemployment. To what extent, however, are the resulting differences independent of the contexts or, conversely, reflections of each territory's characteristic normativities?

The narratives of the unemployed women in the mothers group occupy specific positions on the map, with the largest number invariably clustered around the position of withdrawal from economic activity. These withdrawal processes are ambiguous and ambivalent, since they arise within and in turn modulate the condition of joblessness. Reflecting a dual position — in the world of work and in the domestic sphere - these interpretations reveal less a desire for withdrawal than accommodations between the difficulties of re-entering employment and the constraints of family roles, compromises which arise from the sexual division of labor. Moreover, there are no solid and protective positions to which they could fall back, where both rejection of employment and withdrawal from unemployment would be possible. As a result, there is a risk that they may drift into discouragement and become trapped in unemployment without end. These specificities of the mothers' relations to unemployment vary between the contexts. They are more marked in Tokyo, where it is difficult to combine work commitments and responsibilities for the raising of young children, a fact that strongly influences the interpretations of unemployment. The situation in Paris is somewhat similar, although the interpretations of unemployment are more diverse, in particular with regard to possible alternative options based on protective statuses. In these two contexts, the mothers who differ most sharply from the disparate forms of withdrawal, and who show the greatest motivation to find work, are also those who are closest to the managers in their characteristics (in terms of education and career history), as if these social factors mitigated the influence of gender-based social relations. Finally, the mothers manifest fewer of these specific features in São Paulo, where a significant proportion of them also interpret unemployment in terms of involvement in informal productive activities, reinforcing the impact of the reference biographical experience.

The narratives presented by the unemployed in the youngsters group situate them markedly on the employment side, and away from discouragement or withdrawal into inactivity (with the exception of girls who are pregnant or already have small children, whose profile therefore resembles that of the mothers). Overall, unemployment is perceived by the youngsters as anticipation of employment, which entails different investments: active and targeted jobseeking, adherence to a more or less specific career plan, paid work with varying degrees of legitimacy and potential for conversion into official jobs, participation in training courses, etc. This proximity to employment, subjectively experienced, is supported by norms and institutions that differ from one country to the next, but which contribute to a framing of biographical experience. In the Paris region, the variety of public policies designed to facilitate youth employment and the development of fragile or intermittent forms of employment, generate statuses that are intermediate between unemployment and employment. These situations are interpreted and assumed in different ways, but they tend to position the youngsters close to salaried status, and underpin and frame youth experiences of unemployment. In Tokyo, certain atypical forms of employment are also targeted at young people and promote the two-way flow between unemployment and employment. This means that the youngsters are clearly present on the labor market and in the jobseeking process, but the weakness of public support can undermine their commitment to employment, especially in the 

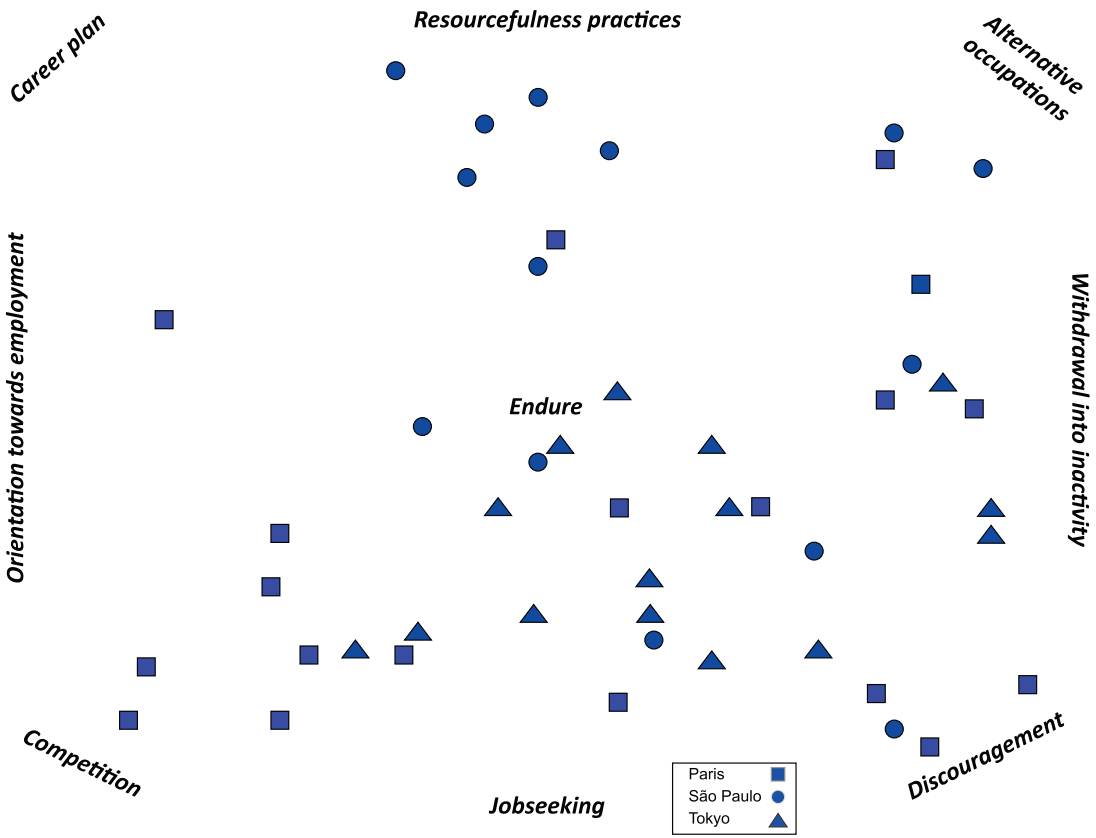

Fig. 5. Map of the mothers target group in the three conurbations.
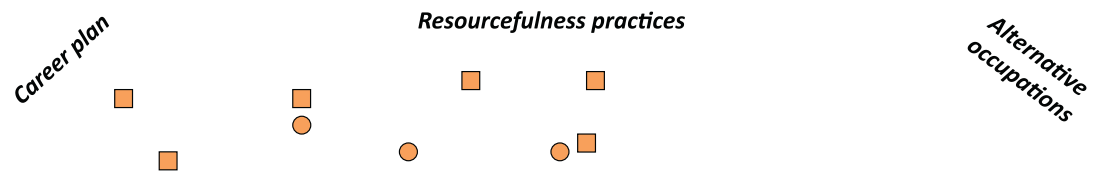

○

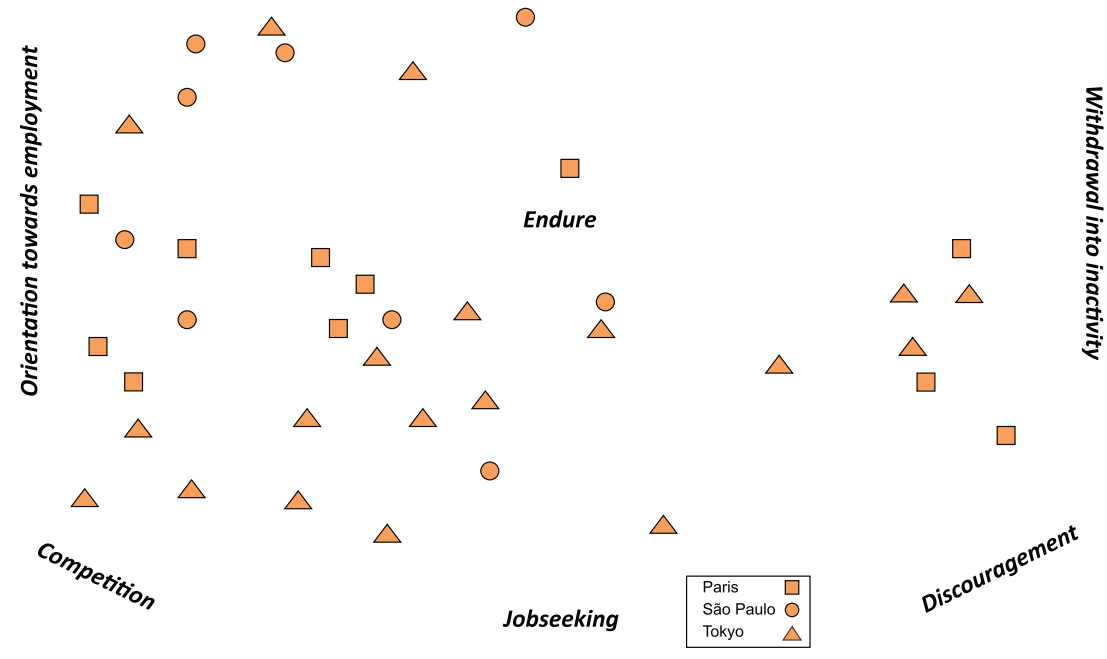

Fig. 6. Map of the youngsters target group in the three conurbations. 


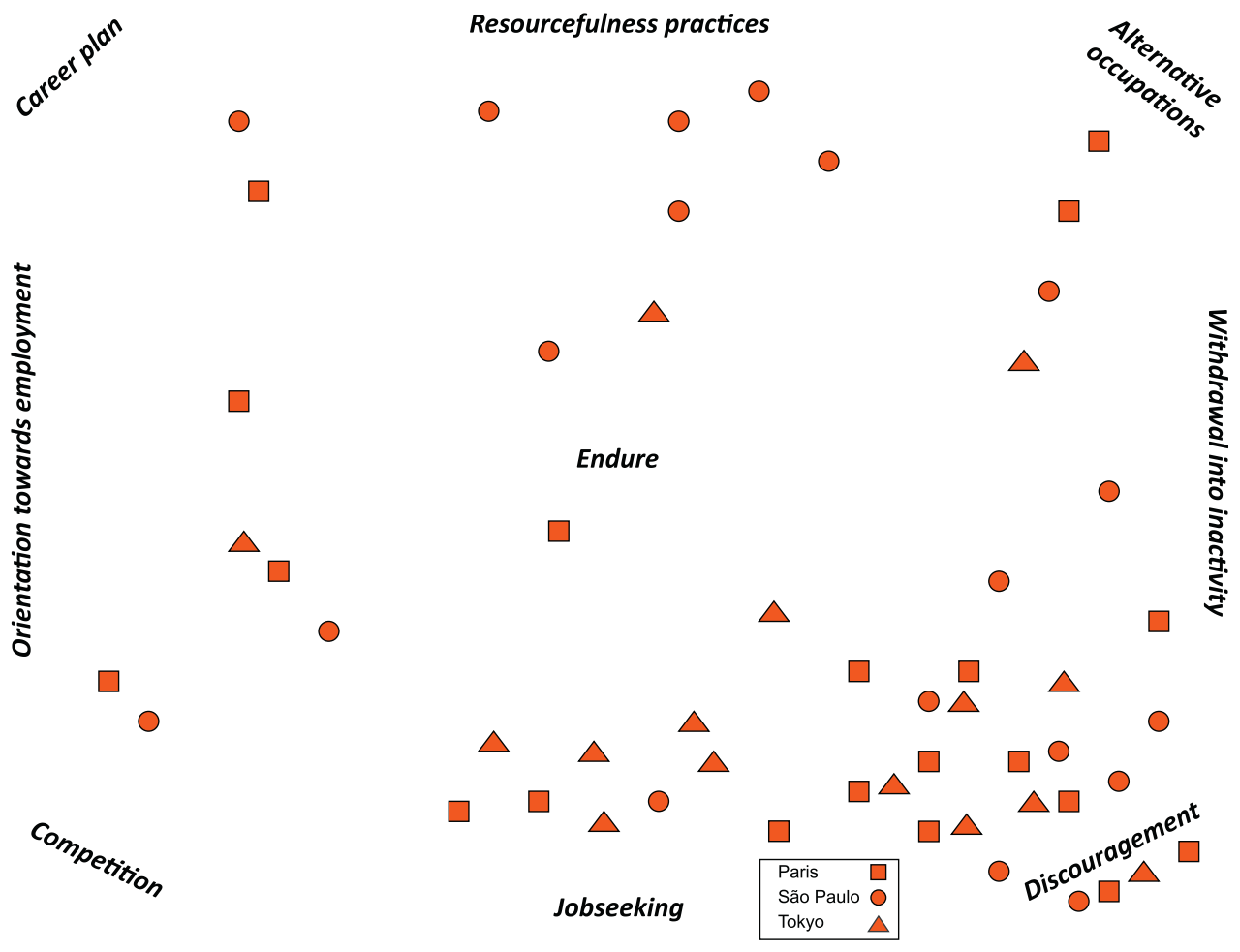

Fig. 7. Map of the workers target group in the three conurbations.

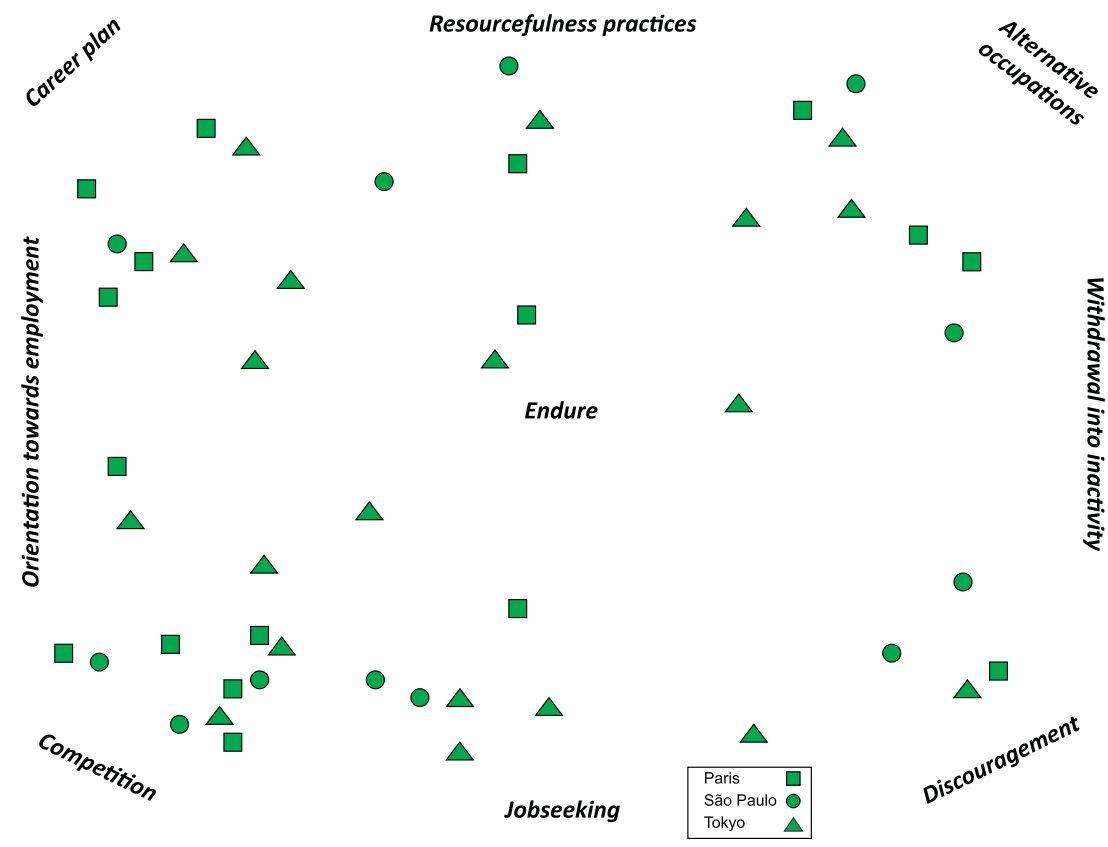

Fig. 8. Map of the managers target group in the three conurbations. 
case of girls. In São Paulo, informal activities that bring varying levels of income have a specific attractor role, which sustains the definitions of situation that combine the contribution to family solidarity, the economic benefits of the activity practiced and projection towards more official or better paid jobs.

There are sharp contrasts between the narratives of the managers and of the workers in all three contexts. For the workers, the experience of unemployment falls within a space bounded by jobseeking and discouragement, i.e. in a zone where the meaning of unemployment is likely to decline into an empty, painful and traumatic ordeal. This very marked tendency reflects a twofold process: distance from employment and the threat of marginalization. By contrast, the manager group's definitions of situation are very differently positioned. It is they who display the most scattered distribution, but two-thirds occupy positions close to those of the youngsters, i.e. with employment as an attractor, where variations arise from typical experiences specific to each context. These differences between workers and managers reflect inequalities in employability and employer appeal, which help to mold the biographical experience of unemployment. Nonetheless, there is interaction between social inequalities and age-related social relations, since the oldest workers and managers tend to move towards the situation of definitive inactivity or, especially in Paris, towards certain protected niches (age-related measures). The older managers are generally free of discouragement, since their narratives are organized around the development of alternative occupations conceived as a means of expunging the difficulty in finding employment.

\section{Figurations of unemployment}

The interpretative comparison presented here casts light on the contemporary transformations of unemployment by elucidating the meanings invested by those who experience it. It would seem that these - indigenous - meanings differ from the statistical and legal codification of unemployment based on the norm of jobseeking. However, their heterogeneity in no way implies that they are dissolved or diluted in individual biographical singularities. Rather, the international comparison of the ways in which unemployment is described, interpreted and apprehended reveals several nested levels of categorization: international, with the sharing of a common universe of reference which places them on a single map of meanings; national, with the expression of normative models that demarcate the condition of unemployment in a way specific to each territory; transnational, with the impact of social relations that span national borders and hold true everywhere in somewhat similar ways. We were able to place these levels of analysis on a single map, thereby constituting a relevant representation for an understanding of the variety and variations in the meanings of unemployment.

The permutations of proximities and distances identified arise from the combination of institutional and normative properties (based on international and national codifications) and social and biographical properties (based on social relations specific to each subjective experience). Depending on the focus of analysis, the findings show the force of normative models, but without eradicating the margins of individual interpretation, or indeed the power of biographical components, and also without eliminating contextual specificities. Drawing on an approach firmly anchored in the survey, we find ourselves back with figuration theory, often referred to in a vague and general manner, but ultimately little used and implemented in contemporary sociological research (Heinich, 1997). Its basic principle is close to the interpretative comparison presented here, since figuration involves "the simultaneous consideration of institutional structures and individuals' lived experience of those structures" (Elias, 1969). The institutional and subjective components are differentiated, but also interdependent, and the ways in which they connect are 
not uniform but vary according to multiple schemas, since they depend on changes in structural dynamics and subjective processes.

Unemployment is therefore not only a status, legally codified and statistically normalized. Nor is it reducible to an experience, individually lived and subjectively endured. It should be considered as a web of normativities, which vary between places and eras, and subjectivities, which vary according to positions and life experiences. It is a "net [...] made up of multiple interwoven threads" (Elias, 1987), normative threads and subjective threads, and this net changes shape when there is an alteration in the position of certain threads and a shift in the tensions that structure the whole. If we follow this view, the comparison can be seen as identifying figurations of unemployment which are both differentiated (between the three societal contexts studied and between the social qualities of the unemployed) and copresent on a single map of meanings (common to the three contexts and associated with the same social relations). Figurations that are simultaneously international, national and transnational.

\section{Declaration of interest}

The author declares that he has no conflicts of interest with regard to this article.

\section{References}

Barbier, J.-C., Letablier, M.-T. (Eds), 2005. Politiques sociales. Enjeux méthodologiques and épistémologiques des comparaisons internationales. Peter Lang, Bruxelles.

Bayart, J.F., 2008. Comparer par le bas. Sociétés politiques comparées 1, 1-25.

Benoit-Guilbot, O., 1987. Les Structures sociales du chômage en France and en Grande-Bretagne. Influences sociétales. Sociologie du travail 29 (2), 219-226.

Benoit-Guilbot, O., 1989. Quelques réflexions sur l'analyse sociétale : l'exemple des régulations des marchés du travail en France and en Grande-Bretagne. Sociologie du travail 31 (2), 217-225.

Benoit-Guilbot, O., Gallie, D., 1992. Chômeurs de longue durée. Actes Sud, Arles.

Castel, R., Fitoussi, J.-P., Freyssinet, J., Guaino, H., 1997. Chômage : le cas français. La Documentation française, Paris.

Cézard, M., 1986. Le chômage et son halo. Économie et statistique 193-194, 77-82.

Chardon, O., Goux, D., 2003. La nouvelle définition européenne du chômage BIT. Économie et statistique 362, 67-83.

Demazière, D., 2002. Chômeurs âgés and chômeurs trop vieux. Articulation des catégories gestionnaires and interprétatives. Sociétés contemporaines 48 (4), 109-130.

Demazière, D., 2006. Sociologie des chômeurs. La Découverte, Paris.

Demazière, D., Dubar, Cl., 2004. Analyser les entretiens biographiques. L'exemple des récits d'insertion. Presses de l'Université de Laval, Québec.

Demazière, D., Guimarães, N.A., Hirata, H., Sugita, K., 2013. Être chômeur à Paris, São Paulo, Tokyo. Une méthode de comparaison internationale. Presses de Sciences Po, Paris.

Desrosières, A., 2003. Comment fabriquer un espace de commune mesure? Harmonisation des statistiques and réalisme de leurs usages. In: Lallement, M., Spurk, J. (Eds), Stratégies de la comparaison internationale. CNRS éditions, Paris, pp. $151-166$.

Elias, N., 1985. La Société de cour. Paris, Flammarion (original edition: Elias, N. 1969. Die höfische Gesellschaft. Untersuchungen zur Soziologie des Königtums und der höfischen Aristokratie. Neuwied/Berlin, Luchterhand).

Elias, N., 1991. La Société des individus. Fayard, Paris (original edition: Elias, N. 1987. Die Gesellschaft der Individuen. Suhrkamp Verlag, Frankfurt).

Eloy, J.-Y., Vanderpotte, G., 1973. Ambiguïtés des définitions du chômage. Sociologie du travail 15 (3), 293 -306.

Freyssinet, J., 1984. Le chômage. La Découverte, Paris.

Glaser, B., 1978. Theoretical Sensitivity. University of California Press, San Francisco.

Glaser, B., Strauss, A., 1967. Aldine. The Discovery of Grounded Theory. Strategies for Qualitative Research, Chicago.

Goux, D., 2003. Une histoire de l'Enquête emploi. Économie et statistique 362, 41-57.

Hall, P., 2001. Global City-Regions in the Twenty-First Century. In: Scott, A.J. (Ed.), Regions and the World Economy: the Coming Shape of Global Production, Competition and Public Order. Oxford University Press, Oxford, pp. 59-77. 
Hegewisch, A., 1998. À mi-chemin entre l'Amérique and l'Europe, les femmes and le chômage en Grande-Bretagne. In: Maruani, M. (Ed.), Les Nouvelles Frontières de l'inégalité. Hommes and femmes sur le marché du travail. La Découverte-Mage, Paris, pp. 234-247.

Heinich, N., 1997. La sociologie de Norbert Elias. La Découverte, Paris.

Jean, S., 2000. Emploi : les enseignements de l'expérience néerlandaise. Économie et statistique 332-333, $133-157$.

Jobert, A., Marry, C., Tanguy, L. (Eds), 1995. Éducation et travail en Allemagne, Grande-Bretagne et Italie. Armand Colin, Paris.

Kase, K., Sugita, K. (Eds), 2006. The Unemployed and Unemployment in an International Perspective: Comparative Studies of Japan,France and Brazil. Université de Tokyo. ISS Research Series, Tokyo.

Lallement, M., Spurk, J. (Eds), 2003. Stratégies de la comparaison internationale. CNRS éditions, Paris.

Lazarfeld, P., Jahoda, M., Zeisel, H., 1981. Les Chômeurs de Marienthal. Minuit, Paris (original edition: Lazarfeld, P., Jahoda, M. Zeisel, M., 1933. Die Arbeitslosen von Marienthal. Hirzel, Leipzig).

Ledrut, R., 1966. Sociologie du chômage. PUF, Paris.

Mansfield, M., Salais, R., Whiteside, N., 1994. Aux sources du chômage, 1880-1914. Une comparaison interdisciplinaire entre la France and la Grande-Bretagne. Belin, Paris.

Maruani, M., 2002. Les Mécomptes du chômage. Bayard, Paris.

Paugam, S., Gallie, D., 2004. L'Expérience du chômage: éléments pour une comparaison européenne. Revue suisse de sociologie 3, 441-460.

Puga, D., Venables, A., 1999. Agglomeration and Economic Development: Import Substitution versus Trade Liberalisation. The Economic Journal 109 (455), 292-311.

Quine, W., 1960. Word and Object. MIT Press, New York.

Salais, R., Baverez, N., Reynaud, B., 1986. L'Invention du chômage. Histoire et transformation d'une catégorie en France des années 1890 aux années 1980. PUF, Paris.

Schnapper, D., 1981. L'Épreuve du chômage. Gallimard, Paris.

Scott, A.J. (Ed.), 1998. Regions and the World Economy: the Coming Shape of Global Production, Competition and Public Order. Oxford University Press, Oxford.

Storper, M., 1997. Regional Economies as Relational Assets, Working paper, 46 p.

Thomas, W.I., 1923. The Unadjusted Girl, with Cases and Standpoint for Behaviour Analysis. Little, Brown and Co, Boston.

Topalov, Ch., 1994. Naissance du chômeur 1880-1910. Albin Michel, Paris.

Valensi, L., 2002. L'exercice de la comparaison au plus proche, à distance : le cas des sociétés plurielles. Annales. Histoire, sciences sociales $1,27-30$.

Wimmer, A., Glick Schiller, N., 2002. Methodological nationalism and beyond: nation-state building, migration, and the social sciences. Global Networks 4 (2), 301-334.

Zimmermann, B., 2001. La Constitution du chômage en Allemagne. Entre professions et territoires. Éditions de la Maison des sciences de l'homme, Paris. 